\title{
-Review-
}

\section{Introduction of Various Vietnamese Indigenous Pig Breeds and Their Conservation by Using Assisted Reproductive Techniques}

\author{
Thanh Quang DANG-NGUYEN ${ }^{1-3)}$, Nguyen Khac $\mathrm{TICH}^{4)}$, Bui Xuan NGUYEN ${ }^{3)}$, \\ Manabu OZAWA' ${ }^{5}$, Kazuhiro KIKUCHI ${ }^{5)}$, Noboru MANABE'), Jozsef RATKY ${ }^{7}$, \\ Yukio KANAI ${ }^{2)}$ and Takashi NAGAI ${ }^{1)}$
}

\begin{abstract}
${ }^{1)}$ Department of Animal Breeding and Reproduction, National Institute of Livestock and Grassland Science, Ibaraki 3050901, 2) University of Tsukuba, Ibaraki 305-8577, Japan, ${ }^{3)}$ Institute of Biotechnology, Vietnamese Academy of Science and Technology, Hanoi, ${ }^{4)}$ Hanoi Agriculture University, Hanoi, Vietnam, ${ }^{5)}$ Department of Animal Science, National Institute of Agrobiological Sciences, Ibaraki 305-8602, ${ }^{6}$ Graduate School of Agricultural and Life Sciences, University of Tokyo, Ibaraki-Kasama 319-0206, Japan and ${ }^{7)}$ Research Institute for Animal Breeding and Nutrition, H-2053 Herceghalom, Hungary
\end{abstract}

\begin{abstract}
Pigs are one of the most important domesticated animals in Vietnam. They are the main source of meat for the Vietnamese. According to FAO statistics, Vietnam is among the top 5 countries raising pigs in the world, with nearly 27 million hogs. This review article introduces the distribution, morphology, growth potential, meat-producing ability and reproductive efficiency of six Vietnamese indigenous pig breeds: I, Mong Cai, Muong Khuong, Soc, Meo and Co. The collected data showed that these Vietnamese pigs are less effective in comparison with Western pigs in terms of reproductive and meat-producing ability as well as weight growth. However, these Vietnamese indigenous breeds have some special characteristics, such as very early sexual maturity, and good adaptability to harsh raising conditions or poor feeding. Moreover, recent genetic research has shown that Vietnamese pigs are genetically diverse. Thus, conservation of these pig breeds using assisted reproductive techniques is urgent and important.
\end{abstract}

Key words: Conservation, Growth, Meat, Pig, Reproduction, Vietnam

(J. Reprod. Dev. 56: 31-35, 2010)

$\mathbf{T}$ he pig makes a major contribution to the world's meat supply. Within the global context, it constitutes the most important source of meat (40\%), followed by cattle (29\%). It is expected that pig meat will remain the single most important meat source, hence playing a pivotal role, particularly in the case of meat production in Asia. In view of the growing human population, pig production continues to play a significant role, which gives rise to an urgent need to sustain research in the field as well as to advance existing reproductive technologies to enable improved and efficient production of piglets to ensure the safeguard of sustainable food production. In addition, pigs are considered a suitable source of cells and organs for xenotransplantation for replacement of those of humans. The newest achievement in producing human immunologically compatible piglets (3-galactosyltransferase knockout pigs), particularly those of non-Porcine Endogenous Retrovirus (PERV) miniature breeds of swine with human-sized organs [1, 2], might spur creation of a humanized biomedical industry. However, we are losing these resources because more and more swine breeds are at risk, mainly due to globally standardized economical pig production, which forces pig farmers all over the world to choose to raise only a few breeds, such as Duroc, Landrace and Large White.

Pigs and humans have been interacting for 10,000 years. Wild boars were important prey animals for early hunter-gatherers across

Received: September 25, 2009

Accepted: September 30, 2009

(C)2010 by the Society for Reproduction and Development

Correspondence: T Nagai (e-mail:taku@affrc.go.jp) wide areas of Eurasia until the early Holocene [3]. During the Neolithic Revolution, this predator-prey relationship radically shifted as wild pigs and several other large mammals were domesticated. Extensive zooarcheological records suggest that pigs were first domesticated about 9,000 years ago in the Near East [4], whereas more recent molecular and archaeological evidences suggest a second independent domestication of pigs in the Far East [5, 6]. Mitochondrial DNA (mtDNA) sequences from 686 wild and domestic pig specimens place the origin of wild boar in Island Southeast Asia (ISEA), where they dispersed across Eurasia, and new genetic data reveal not just one or two, but, multiple centers of domestication across Eurasia [7].

Many breeds and varieties of pigs originated from these domestication centers. The estimated number of pig breeds being raised currently is 649 [8]. This number reflects their major use. However, pigs do not provide any secondary products such as milk and wool, nor do they have additional uses such as transport or power, as do some other common farmyard animals. Thus, the modern pig industry only focuses on meat efficiency in selection of "good pigs". Furthermore, under human selection force, only economically efficient breeds receive sufficient care from human beings, while others have been ignored and are facing major population loss. This leads to the fact that as many as 47 breeds are categorized as critical, another 85 breeds are endangered and 151 breeds have become extinct [8]. These statistics show clearly the serious loss of porcine bio- and genetic diversity.

Since it belongs to Southeast Asia, one of the earliest domestica- 
tion centers of pigs, interaction with pigs quickly developed in ancient Vietnam. The pig has been one of the most important domesticated animals in Vietnam. Pigs appear frequently in Vietnamese folk art such as in verses, paintings, songs, and legends. They are always portrayed as being slumped in Dong Ho Paintings, one of the most distinct Vietnamese folk arts, as a symbol of being well-fed, wealthy and happy (Fig.1). More precisely, the pigs depicted in the paintings are the "I" breed, one of the indigenous breeds of Vietnam. Other breeds which are also considered as indigenous include the Mong Cai, Muong Khuong, Soc, Meo and Co.

Pigs have been the main source of meat for the Vietnamese. According to FAO statistics [9], Vietnam is among the top 5 countries raising pigs in the world, with nearly 27 million hogs. However, most of these pigs are Landrace, Large White, Duroc or crossbreeds between them, while the numbers of the above mentioned indigenous breeds have been decreasing dramatically. Thus, the loss of these indigenous breeds means loss of an abundant reservoir of genetic diversity of domesticated pigs, and conservation activities are urgently needed.

In this review, we introduce some information about the genetic diversity, reproductive efficiency, growth potential, meat-producing ability, morphology, and distribution of six Vietnamese indigenous pig breeds, I, Mong Cai, Muong Khuong, Soc, Meo and $\mathrm{Co}$, and review their conservation using artificial reproductive technologies.

\section{Genetic Diversity and Conservation of Vietnamese Indigenous Pigs Using Artificial Reproductive Technologies}

Collaborative research between Japanese and Vietnamese scientists has been performed to compare the mitochondrial DNA sequences of Vietnamese domestic pigs with those of domestic breeds from other regions of Asia [10]. That study showed that Vietnamese domesticated pigs are genetically diverse and relatively close to East Asian pigs. Research using microsatellites to compare Western pig breeds with some Vietnamese indigenous porcine breeds, including the Mong Cai, Muong Khuong, Meo and Co, has revealed that the Vietnamese breeds harbor a considerable amount of genetic diversity [11]. Recently, research on the mitochondrial diversity of native pigs in mainland South and South-east Asian countries, including Vietnam, has been performed [12]. That study suggested that maternal introgression from European domestic pigs has had no or little impact on Vietnamese pigs since no European mitochondrial DNA haplotypes were detected among the samples. It also suggested that although some local Vietnamese breeds may have a historically Chinese origin, they are now unique due to a long history of the breed improvement and fixation to acquired biological fitness. The results from these studies suggest that Vietnamese indigenous pigs have a high value of genetic diversity, and they are imperatively needed to be conserved.

Theoretically, it would be better to implement ex situ conservation programs before an animal population becomes threatened. However, the populations of Vietnamese pig breeds are becoming small and fragmented. Thus, the conservation should be accom- plished by breeding programs to retain the maximal gene diversity while avoiding inbreeding depression and minimizing genetic drift, demographic bottlenecks and founder effects. The basis for success is ensuring populations and individuals to produce offspring of known provenance and appropriate genotype in these rare breeds. For these reasons, there has been substantial interest in the application of assisted reproductive techniques (ART), including artificial insemination, in vitro fertilization (IVF), somatic cell nuclear transfer and embryo transfer using fresh or frozen-thawed gametes and embryos. This also includes the concept of developing Genome Resource Banks (GRBs), that is, organized repositories of frozen biomaterials. Establishing GRBs in concert with ART has potential for preserving genetic diversity of many endangered breeds.

In an effort to conserve these minipigs, ARTs have been used to produce embryos in vitro from Meo pigs $[13,14]$. Somatic cells and spermatozoa from Meo mini-pigs were collected and preserved in a cryobank in the framework of a VAST-JSPS project between Japan and Vietnam. The above studies showed that ARTs that have been used for Western pigs can be applied conveniently to Vietnamese pigs. The in vitro-produced embryos were transferred to either a Meo or Mong Cai sow. Nevertheless, no pregnancies have been obtained due to the small number of transferred embryos, since the embryos recovered from recipients appeared to be normal (personal communication). So, it is important to significantly increase the blastocyst formation rate because of the limited number of oocytes recovered from miniature pigs. Many efforts have been made to improve in vitro production (IVP) of blastocysts, since this is one of the top priorities for pigs. The development of an optimal culture medium has also been a research focus in recent years. Along with adding various compounds into in vitro culture media, the culture conditions have also been also optimized by use of 5\% carbon dioxide and 5\% oxygen. Although those efforts have improved the efficacy of the porcine IVP system, the system is still considered inefficient. It is necessary to use and develop some proper technique in order to dramatically change the blastocyst formation rate.

In recent research, halving 2-cell embryos into 2 single blastomeres possibly doubled the blastocyst formation rate in pigs (unpublished data). These results are expected to be applied to Vietnamese domestic pigs in the near future. Twin blastocysts produced from the same 2-cell embryos can also be transferred to suitable recipients to achieve high pregnancy rates, resulting in many live piglets on the ground.

\section{Reproductive Efficiency}

The growth potentials of I, Mong Cai, Muong Khuong, Soc, Meo and Co pigs are shown in Table 1 [15]. Except for the Mong Cai, the other breeds have a lower litter size compared with Western pigs raised in Vietnam; 10-12 piglets for Landrace and 10-13 piglets for Yorkshire.

The numbers of parturitions per year of Landrace (2 to 2.2) and Yorkshire (2 to 2.1) pigs are also higher that those of Vietnamese indigenous pigs (1.1 to 1.4, except for Mong Cai).

However, some Vietnamese breeds show a surprisingly early age of sexual maturity. For example, Co pigs are mature at the age 
Table 1. Reproductive efficiency of Vietnamese pig breeds

\begin{tabular}{lcccccc}
\hline Parameters & I & Mong Cai & Muong Khuong & Soc & Meo & Co \\
\hline Estrus cycle (days) & $19-21$ & 21 & $20-21$ & $20-21$ & $21-22$ & $21-22$ \\
Length of estrus (days) & $3-4$ & $3-4$ & $5-7$ & $4-5$ & $5-6$ & $5-6$ \\
Age at first estrus (months) & $4-5$ & $6-8$ & $6-7$ & $6-9$ & $8-9$ & $2-3$ \\
Number of parturitions per year & $1.6-1.7$ & $1.5-2$ & $1.2-1.3$ & $1.1-1.2$ & $1.2-1.4$ & $1.2-1.3$ \\
Litter size & $8.8-11.3$ & $10-14$ & 5 & $6-10$ & $6-7$ & $6-7$ \\
Weight of weaned pig (kg) & $3-4$ & $6-7$ & $5-6$ & $5-6$ & $4-5$ & 3 \\
Parturition interval (months) & $6-7$ & $5-6$ & $9-10$ & $10-11$ & $9-10$ & $9-10$ \\
\hline
\end{tabular}

a Although female "I pigs" show estrus and are able to become pregnant at the age of 4 to 5 months, the first mating should be at the age of 8 months because of their low weight (about $20 \mathrm{~kg}$ ).

Table 2. Weight growth ${ }^{\mathrm{a}}$ of Vietnamese pig breeds

\begin{tabular}{|c|c|c|c|c|c|c|c|}
\hline \multirow{2}{*}{$\begin{array}{l}\text { Age } \\
\text { (month) }\end{array}$} & \multicolumn{2}{|c|}{ I } & \multirow[t]{2}{*}{ Mong Cai } & \multirow{2}{*}{$\begin{array}{l}\text { Muong } \\
\text { Khuong }\end{array}$} & \multicolumn{2}{|c|}{ Soc } & \multirow[t]{2}{*}{ Meo } \\
\hline & Pha & Mo & & & Loose & Captive & \\
\hline Infant & 0.42 & 0.45 & 0.45 & 0.6 & \multicolumn{2}{|c|}{$0.4-0.45$} & 0.48 \\
\hline 2 & 4.4 & 4.5 & 6 & 5.5 & 3.8 & 4.15 & 4.2 \\
\hline 3 & 7.5 & 7.30 & 10 & 9.90 & 7.90 & 9.0 & 9.5 \\
\hline 4 & 13.5 & 13 & 14 & 16.5 & 12.8 & 15.2 & 13 \\
\hline 6 & 24.90 & 22.5 & 25 & 27.88 & 17.45 & 19.4 & 25 \\
\hline 9 & 39.9 & 41.3 & 45 & 54.13 & 24.2 & 31.0 & 43.9 \\
\hline 12 & 48.2 & 50.5 & 54 & 69.31 & 30.57 & 40.42 & 64.2 \\
\hline$>12$ & $50-60$ & $60-65$ & $75-80$ & 92.44 & 50.87 & 50-55 & 114.9 \\
\hline
\end{tabular}

${ }^{\text {a }}$ Weights are indicated in $\mathrm{kg}$.

Table 3. Meat-producing ability of Vietnamese pig breeds

\begin{tabular}{|c|c|c|c|c|c|c|c|c|}
\hline & \multicolumn{3}{|c|}{ I } & \multirow{2}{*}{$\begin{array}{l}\text { Mong } \\
\text { Cai }\end{array}$} & \multirow{2}{*}{$\begin{array}{l}\text { Muong } \\
\text { Khuong }\end{array}$} & \multicolumn{2}{|c|}{ Soc } & \multirow[b]{2}{*}{ Co } \\
\hline & Mo & Pha & Thanh Hoa & & & Captive & Loose & \\
\hline Carcass proportion ${ }^{\mathrm{a}}(\%)$ & 62.7 & 64.1 & 63.3 & $68-70$ & $64.1-69.8$ & 77.7 & 75 & $50-55$ \\
\hline \multicolumn{9}{|l|}{ Carcass composition } \\
\hline Fat (\%) & 48.2 & 42.6 & 41.8 & $35-36$ & $29-38.8$ & 38.2 & 32.2 & 35.1 \\
\hline Bone (\%) & 8.8 & 10.5 & 10.6 & 12.6 & 13.5 & 14.5 & 15.0 & 14.3 \\
\hline Lean meat (\%) & 30.2 & 33.5 & 33.5 & $35-38$ & $39.8-40.4$ & 34.4 & 43.8 & 40.2 \\
\hline
\end{tabular}

${ }^{a}$ Carcass proportion is the ratio of the body of the slaughtered animal after the removal of the offal to the body weight of the live animal.

of 2 to 3 months. Mong Cai boars also reach puberty at the age of 2 months and their sperm are fully capable of fertilizing females. I boars even start to practice jumping on females' backs at 3 to 4 weeks old and sperm from 40-day-old boars are able to fertilize females and produce piglets. This special character is likely to have benefits for production efficiency. Thus, conservation of these pig breeds is important for the future.

\section{Growth Potential and Meat-producing Ability}

The growth potentials and meat-producing abilities of the 6 Vietnamese indigenous pigs are shown in Tables 2 and 3, respectively [15]. The data reveal a large difference in weight between Vietnamese and Western pigs (raised in Vietnam).

The infant weights of the 6 Vietnamese breeds range from 0.4 to
$0.6 \mathrm{~kg}$ and are lighter compared with the $1.2-1.3 \mathrm{~kg}$ of the infant Landrace. A six-month-old adult Landrace or Duroc pig weighs around $100 \mathrm{~kg}$, whereas the weight varies from 17.45 to $27.88 \mathrm{~kg}$ among the adults of the Vietnamese breeds.

The Western breeds raised in Vietnam also have a higher proportion of lean meat (52-55\% for Yorkshire, 54-56\% for Landrace and $58-60 \%$ for Duroc) compared with the 6 Vietnamese indigenous pigs (30.2-46.4\%).

These statistics show clearly that Western pigs are much more effective for meat production than Vietnamese indigenous pigs. The Western pigs are well-known for their great adaptation ability. Nevertheless, no reports have shown the possibility of raising these Western breeds in the mountainous regions where local Vietnamese pigs are raised loosely (rather than captive) in a harsh climate under poor feeding conditions. This partly explains why the local 


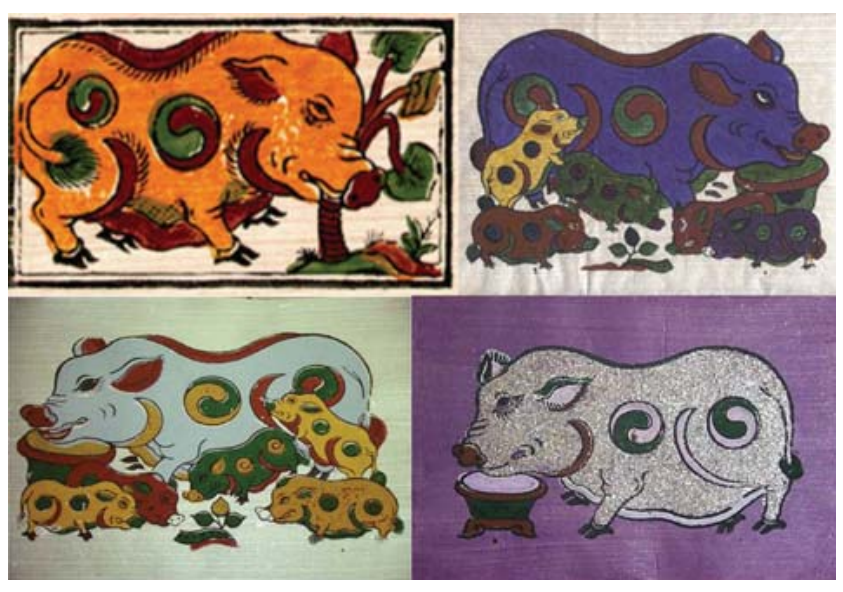

Fig. 1. Pigs in Dong Ho Paintings. This Vietnamese woodblock print is a distinct Vietnamese folk art originating in Dong Ho Village, Bac Ninh Province, which is north of Hanoi.

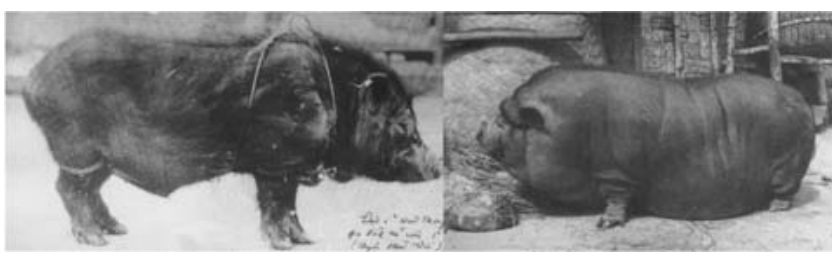

Fig. 2. I pigs: boar (left), sow (right).

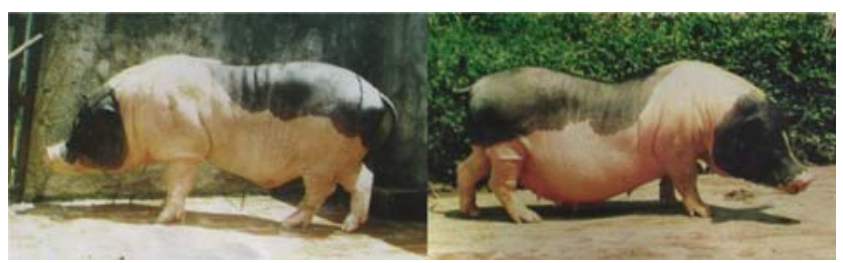

Fig. 3. Mong Cai pigs: boar (left), sow (right).

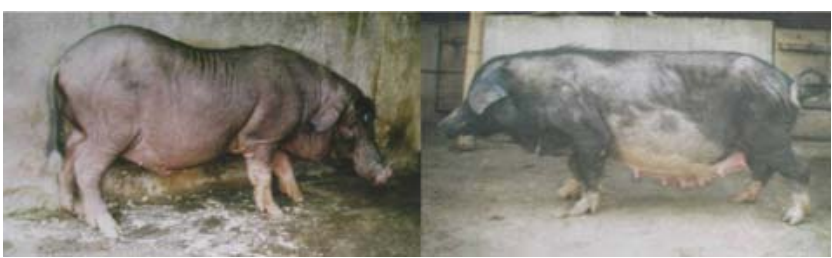

Fig. 4. Muong Khuong pigs: boar (left), sow (right).

breeds, including the Soc, Meo and Muong Khuong, are still raised in mountainous regions in spite of the fact that the Western breeds are far superior in growth potential and meat-producing ability.

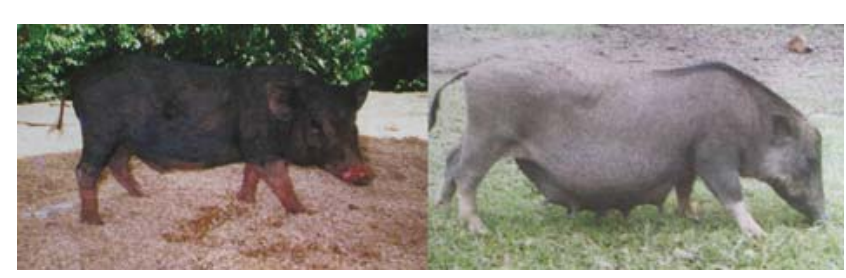

Fig. 5. Soc pigs: boar (left), sow (right).

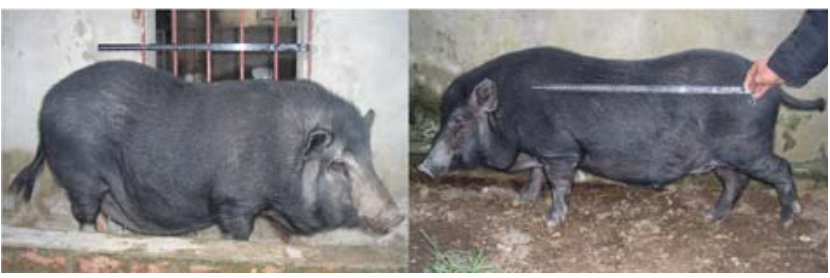

Fig. 6. Meo pigs: boar (left), sow (right).

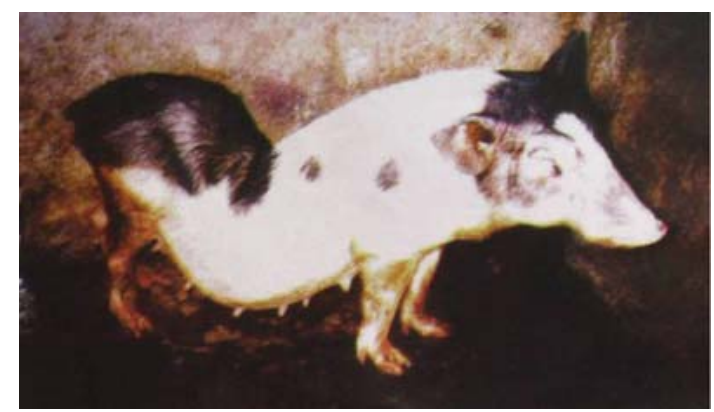

Fig. 7. Co pig.

\section{Morphology}

There are many types of I (shown in Fig. 2), of which the "I mo", "I pha" and "I Thanh Hoa" are the most popular. They have some differences in appearance. The I's hair is short, sparse, black and shinny. Their body and legs are short. They have a sagging back, hanging-down belly, small eyes, big and short mouth and sagging cheeks. Many female I have 2 bandy posterior legs [15].

The Mong Cai (shown in Fig. 3) has thin white hair, white skin, a big head, a small and long mouth, small and pointed ears, a long and sagging back, a hanging-down belly and long legs. Its back and buttocks have black saddle-liked areas. There are 2 races of Mong Cai pig, with big and small bones, respectively. They are little different in morphology [15].

The Muong Khuong's hair is thin, soft and completely black or black-with-white-spots on the head, tail and legs (shown in Fig. 4). This breed has a long, straight or slightly curved mouth, big ears and legs, a large body but thin dorsal area, and a fat belly that does not hang-down [15].

The Soc looks like a wild pig with a small body size and a long 


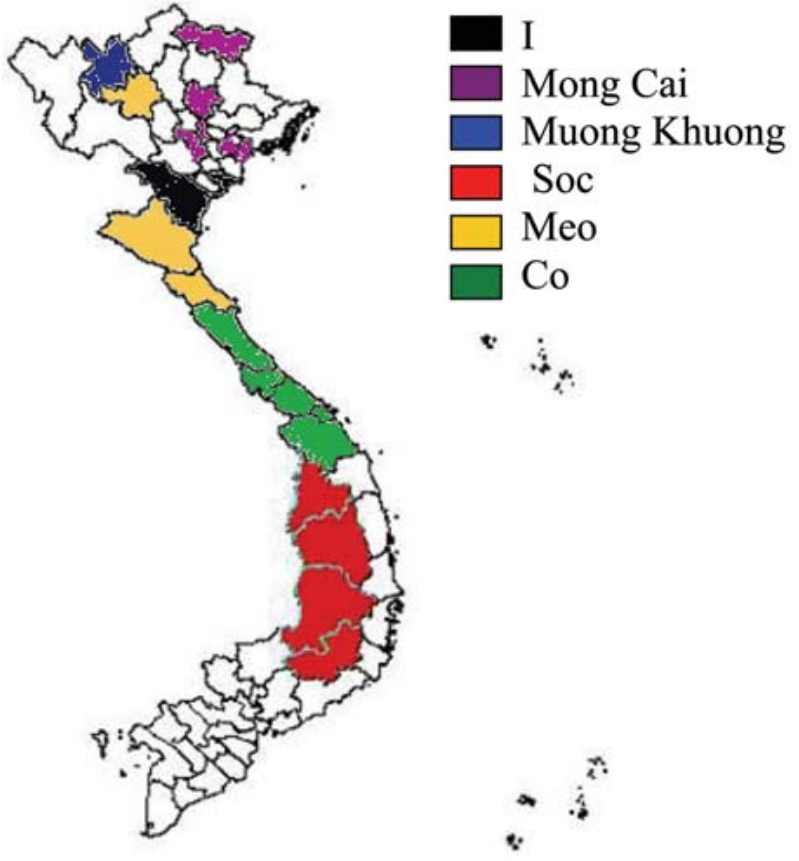

Fig. 8. General distribution of various Vietnamese pig breeds.

and pointed mouth. It has thick skin, long black hair and small legs (shown in Fig. 5). It moves very quickly on its feet. Thus, it is suitable for raising under loose or self-feeding conditions [15].

The Meo has a big and long body with long, hard, black hair and yellow skin (shown in Fig. 6). This breed usually has a large head and large ears, a curved-over back and 6 white spots on its legs, forehead and tail. They sometimes have a white area on their belly [15].

The Co has a small body; the weight of an adult Co is only 30$35 \mathrm{~kg}$ (shown in Fig. 7). This miniature pig always has white and black hair, a long mouth, small bones and a hanging-down belly. The boar is often smaller than the sow. It is unusual to find a boar that weighs over-20kg boar [15].

\section{Distribution}

The general distribution of the six Vietnamese pig breeds is shown in Fig. 8 [15].

Before the 1970s, the "I" was raised widely in many provinces of the Hong River Delta and Thanh Hoa (about 1.5 billion I pigs). Since then, the area in which this breed is raised has become increasingly restricted. Nowadays, only a few villages in Thanh Hoa continuously raise I pigs.

Quang Ninh, a province in Northern Vietnam, is considered to be the homeland of the Mong Cai. During the 1960s and 1970s, this pig was raised throughout the entire Northern delta. Since then, they have been raised in Central Vietnam and some Southern provinces.

The Muong Khuong is a local breed. This pig has long been raised by the H’Mong tribe in Muong Khuong (Lao Cai) and many other mountainous regions of Northern Vietnam.

The Soc is distributed mostly in the minorities' villages of Tay Nguyen. The estimated population of this local breed is about 5,000 .

The Meo is distributed mostly on and around Truong Son Mountain, a cool region. This breed has been acclimatized to free raising. It has been popularly raised by the H'Mong tribe. The Meo pig has also been raised widely in Nghe An, a province in Central Vietnam. Beginning after the 1960s, it has also been nurtured in some other delta districts of this province.

The Co is a miniature pig. Before the 1960s, it was raised in Central Vietnam, especially in Nghe An, Ha Tinh and Binh Tri Thien. This breed used to be a special breed in these provinces. However, it is almost extinct now.

\section{References}

1. Lai L, Kolber-Simonds D, Park K-W, Cheong H-T, Greenstein JL, Im G-S, Samue M, Bonk A, Rieke A, Day BN, Murphy CN, Carter DB, Hawley RJ, Prather RS. Production of $\alpha$-1,3-galactosyltransferase knockout pigs by nuclear transfer cloning. Science 2002; 295: 1089-1092.

2. Phelps CJ, Koike C, Vaught TD, Boone J, Wells KD, Chen SH, Ball S, Specht SM, Polejaeva IA, Monahan JA, Jobst PM, Sharma SB, Lamborn AE, Garst AS, Moore M, Demetris AJ, Rudert WA, Bottino R, Bertera S, Trucco M, Starzl TE, Dai Y, Ayares DL. Production of $\alpha 1,3$-galactosyltransferase-deficient pigs. Science 2003; 299: 411-414.

3. Benecke N. In: Desse J, Audoin-Rouzeau F (ed.), Exploitation des Animaux Sauvages a'travers le Temps. Juan-les-Pins: Editions APDCA; 1993: 233-245.

4. Epstein J, Bichard M. Pig. In: Mason IL (ed.), Evolution of Domesticated Animals. New York: Longman; 1984: 145-162.

5. Giuffraa E, Kijasa JMH, Amargera V, Carlborga Ö, Jeona J-T, Anderssona L. The origin of the domestic pig: independent domestication and subsequent introgression. Genetics 2000; 154: 1785-1791.

6. Jing Y, Flad RK. Pig domestication in ancient China. Antiquity 2002; 76: 724-732.

7. Larson G, Dobney K, Albarella U, Fang M, Matisoo-Smith E, Robins J, Lowden S, Finlayson H, Brand T, Willerslev E, Rowley-Conwy P, Andersson L, Cooper A Worldwide phylogeography of wild boar reveals multiple centers of pig domestication. Science 2005; 307: 1618-1621.

8. FAO. Globe regions-Breeds at risk/ Global summary. In: Scherf BD (ed.), World Watch List for Domestic Animal Diversity 3rd ed. Food Agric. Org. United Nations. Rome, Italy; 2000: 53-63.

9. FAOSTAT. Food and Agriculture Organization of the United Nations, Rome, Italy. 2006.

10. Hongo $\mathrm{H}$, Ishiguro N, Watanobe T, Shigehara N, Anezaki T, Long VT, Binh DV, Tien NT, Nam NH. Variation in mitochondrial DNA of Vietnamese pigs: Relationships with Asian domestic pigs and Ryukyu wild boars. Zoolog. Sci 2002; 19: 13291335.

11. Thuy NTD, Melchinger-Wild E, Kuss AW, Cuong NV, Bartenschlager H, Geldermann H. Comparison of Vietnamese and European pig breeds using microsatellites. J Anim Sci 2006; 84: 2601-2608.

12. Tanaka K, Iwaki $Y$, Takizawa T, Dorji T, Tshering G, Kurosawa $Y$, Maeda $Y$, Mannen H, Nomura K, Dang VB, Chhum-Phith L, Bouahom B, Yamamoto Y, Daing T, Namikawa T. Mitochondrial diversity of native pigs in the mainland South and South-east Asian countries and its relationships between local wild boars. Animal Science Journal 2008; 79: 417-434.

13. Dang-Nguyen TQ, Duc NH, Nguyen-Viet L, Uoc NT, Nagai T, Kikuchi K, Ozawa M, Hanh NV, Thanh NT, Bui LC, Huu QX, Nguyen BX. Conservation of genetic resources of Ban minipig using intracytoplasmic sperm injection. In: Proceedings of 3rd Annual Conference of Asian Reprodutive Biology Society, 2006; Hanoi, Vietnam. Abstract 161.

14. Nguyen BX, Uoc NT, Nagai T, Kukuchi K, Nguyen-Viet L, Dang-Nguyen TQ, Duc NH, Hanh NV, Thanh NT, Bui LC, Huu QX, Minh PN. Effect of gonadotropin treatment on the oocyte collection and in vitro fertilization in Ban minipig. Reprod Fertil Dev 2007; 19: 269-270 Abstract.

15. Ly LV. Animal Genetic Conservation in Vietnam-Part 1. Livestock. Hanoi: Agricultural Press; 1999 (In Vietnamese). 